\title{
Hepatitis B Virus DNA in Sera of Apparently Healthy Carriers Blood Donors with Anti-Hbc Total Positive
}

\author{
Thaer Kadhim Fayyadh ${ }^{1}$, Fuying $\mathrm{Ma}^{1}$ \\ ${ }^{1}$ College Of Life Science And Technology, Huazhong University Of Science And Technology, \\ Wuhan City, Hubei province, China, \\ ${ }^{I}$ Key Laboratory Of Molecular Biophysics Of MOE, College Of Life Science And Technology, \\ Huazhong University Of Science And Technology, Wuhan 430074, China
}

\begin{abstract}
:
Objective this study was attempt to molecular estimation of Hepatitis-B Virus DNA (HBV-DNA) in sera of apparently healthy carriers blood donors with anti-HBc Total positive alone and discussed the reasons that lead to disappearance of HBsAg in their sera. As well as evaluation of the routine screening method of HBV infection among blood donors by ELISA assay.

Methods A total of 100 sera samples were collected from HBsAg-negative blood donors who were attended to the blood bank in Baghdad and examined for anti-HBc IgM, anti-HBc Total and anti-HBsAg. Thereafter samples with anti-HBC Total positive alone were separated and underwent molecular investigation for the presence of HBV-DNA by PCR technique.

Results Out of 100 samples 9 (9\%) had anti-HBc Total positive and $0 \%$ anti-HBc IgM negative. Out of 9 anti-HBc Total positive $6(66.6 \%)$ with anti-HBs positivity and $3(33.33 \%)$ were negative to anti-HBs. Furthermore, $H B V D N A$ among HBsAg negative and anti-HBc Total positive alone was investigated. One case $11.11 \%$ of the latter group was detecting positive for $H B V-D N A$.

Conclusion HBV-DNA is present in sera of blood donors with HBsAg negative, anti-HBc Total positive and anti-HBs negative.
\end{abstract}

Keyword: $H B V$, occult $H B V, H B s A g$ negative, blood donors

\section{Introduction}

Hepatitis B virus (HBV) infection represents a worldwide public health problem that can lead to chronic hepatitis, hepatic cirrhosis, and primary hepatic cancer (Song and Kim, 2016). According to World Health Organization (WHO) estimations, 2 billion of the global populations have contracted HBV infection and 450 million people are chronically infected with $\mathrm{HBV}$ and risk infection with hepatitis D virus (WHO, 2015; $\mathrm{Li}$, et al., 2015). Serological markers for HBV infection consist of hepatitis B surface antigen (HBsAg), anti-HBs, hepatitis B envelope protein ( $\mathrm{HBeAg}$ ), anti-HBe, and hepatitis B core antibody (anti-HBc) IgM and Total, these markers along with the viral load are particularly important in defining the stage of $\mathrm{HBV}$ infections and in their management (Liang, 2009). The HBsAg is the main diagnostic serological marker for HBV infection as well as for the blood screening in the blood bank. Chronic carriers of HBV usually show HBsAg in their serum, which is considered the best marker for acute and chronic HBV infection. The HBsAg, however, sometimes underwent to escape mutation (core or pre-core mutation) might be as a result of post transcriptional effect of the mutation on HBsAg expression as described previously (Hass, et al., 2005). In those individuals, this antigen cannot be detected by routine serological assays (such as ELISA) despite the presence of virus in liver and peripheral blood. One reason for this lack of HBsAg might be mutation in the part of the molecule recognized by specific antibodies (Martinez, et al., 2015).

Although the risk for transfusion-associate HBV infection has been greatly reduced since the screening of blood for HBV serological markers and the exclusion of donors who engage in high-risk activities, the transmission of $\mathrm{HBV}$ infection is still possible when the blood donors are asymptomatic carriers with $\mathrm{HBsAg}$ negative (Luo, et al., 1993; Rios-Ocampo et al., 2014). Occult (Hidden) hepatitis B is defined by the presence of HBV-DNA in serum or liver in the absence of HBsAg (Hu, 2002; Raimondo, et al., 2008). Our study aims to estimate HBV-DNA among blood donors with anti-HBc Total positive alone by PCR technique and determine the sensitivity of routine methods that were used in our laboratories for detection HBV infection.

\section{Materials And Methods}

\section{Subjects and blood specimen's collection}

The study group was randomly selected from blood donation individuals in Baghdad, a total of 100 sera specimens were collected from healthy blood donors, adult males, with mean of ages $32.72 \pm 7.074$ and 
HBsAg negative were identified by ELISA technique to determine the sero-prevalence of anti-HBc IgG and estimate HBV DNA. The detection limit of the HBsAg assay is 0.100 units/ $\mathrm{mL}$ (standards Paul Ehrlich Institute, Germany) and $0.125 \mathrm{IU} / \mathrm{mL}$ (International standards from the World Health Organization (WHO ref. 80/549) (Ferguson, 1985). From each individual, $5 \mathrm{ml}$ of blood was collected as well as 15 positive HBsAg sera specimens were collected from different types of HBV infection patients; 5 specimens from acute hepatitis B (AHB), 5 specimens from chronic hepatitis B patients (CHB) and 5 specimens from apparently healthy carriers (AHC) as a control also to comparison between routine methods and PCR technique. The collected blood was placed in disposable plain tubes, the blood specimens were allowed for $15 \mathrm{~min}$ at room temperature (RT) for clotting. Then, the sera were separated by centrifugation the blood specimens at 3000 RPM for 5 min., thereafter divided into aliquots $250 \mu \mathrm{l}$ (4 tubes for each sample) and stored at $-80^{\circ} \mathrm{C}$ until use. Each part of sera was used once to avoid repeated thawing and freezing. Materials (i.e. reagents and sera) were allowed to stand at RT before use. Specimens were anonymous and identified only by alphanumerical codes, after signing the informed consent provided by the blood bank.

\section{Biochemical and Serological Assays}

Liver function tests, including alanine aminotransferase test (ALT), (normal range, up to $13 \mathrm{u} / \mathrm{l}$ ) and total serum bilirubin (TSB), (normal range, less than 1mg / dl) levels (Young, 1997), were done for all individuals from both groups blood donors and control at initial examination by using commercially available ELISA kits (Randox, UK). Serological markers for HBV were done for each specimen using commercially available ELISA kits (Bioelisa; Biokit, Spain) for HBsAg, anti-HBc IgM, anti-HBc Total and anti-HBs antibodies. The assay for each serological marker was done according to the manufacturer's instruction, and then the ELISA reader was used to measure the absorbance at $450 \mathrm{~nm}$ and the results were interpreted based on the optical density (OD).

\section{Statistical analysis}

Statistical analysis was performed with SPSS software version 15, under windows ${ }^{\mathrm{XP}}$ and Mini. Tab programmers'. Data were analyzed using analysis of paired-samples $T$ test for comparison between different groups. Results were reported as mean \pm S.D and differences were considered as significant when $\mathrm{P}<0.05$.

\section{Detection of HBV DNA by PCR technique}

Sera specimens from each individual with HBsAg negative and "anti-HBc Total positive alone" in the blood donors group and control group were taken at initial examination and they were underwent tested for HBV DNA by using commercially available kit (AB ANALITICA; Italy), which based on the amplification of the core region of HBV DNA by specific primers. HBV DNA was extracted with a high pure viral nucleic acid extraction Kit (AB ANALITICA; Italy) according to manufacturer's instruction. Briefly, in $1.5 \mathrm{ml}$ tube an aliquot of $200 \mu \mathrm{l}$

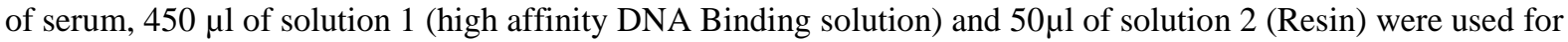
DNA extraction, the mixture was transferred to a filter column and then centrifuged at $12000 \mathrm{~g}$ for $2 \mathrm{~min}$., The filter column that containing resin to which the DNA is bound was transferred into a new $2 \mathrm{ml}$ tube, washed with $500 \mu \mathrm{l}$ of washing buffer, and re-centrifuged at $12000 \mathrm{~g}$ for $2 \mathrm{~min}$. then the filter column was transferred to new and clean $1.5 \mathrm{ml}$ tube, thereafter $80 \mu \mathrm{l}$ of pre-heated $\left(65^{\circ} \mathrm{C}\right)$ sterile distilled water was used to elute the DNA that bound to the resin. An aliquot $(0.2 \mu \mathrm{l})$ of AB Super Taq polymerase and $10 \mu \mathrm{l}$ of extracted DNA elute was then added to each premixed tube. PCR direct amplification was performed for 37 cycles as in table (1)

Table (1): Thermalcycler program of direct PCR amplification

\begin{tabular}{|l|c|c|c|}
\hline \multicolumn{1}{|c|}{ Step } & No. of Cycles & Temp. $\left({ }^{\mathbf{}} \mathbf{C}\right)$ & Time \\
\hline Initial denaturation & 1 & 94 & 5 minutes \\
\hline Denaturation & 35 & 94 & 60 seconds \\
Annealing & & 45 & 60 seconds \\
Extension & 1 & 72 & 60 seconds \\
\hline Final extension & & 72 & 5 minutes \\
\hline Storage of amplified & & 4 & $\infty$ \\
product & & & \\
\hline
\end{tabular}

PCR amplicons were separated by electrophoresis on an agarose $3 \% \mathrm{w} / \mathrm{v}$ gel, stained with ethidium bromide, and visualized under UV light. Standard procedure for reducing contamination was followed strictly. Furthermore, PCR assays for anti-HBc IgG positive alone were performed in duplicate to confirm reproducibility. The obtained results were compared with the reference DNA Molecular Weight Marker (501-489, 404, 353, 242, 190, 147, 110, 89, 67, 34, $26 \mathrm{bp})$ to determination the size of amplified products. Control results and band pattern products were interpreted as in table (2) and table (3). 
Table (2): Interpretation of the control results

\begin{tabular}{|l|l|l|}
\hline Control & Results & Interpretation \\
\hline Positive control & Positive & Amplification correctly work \\
\hline Negative control & Negative & Absence of contamination \\
\hline
\end{tabular}

Table (3): Interpretation of the band pattern products

\begin{tabular}{|l|l|c|}
\hline DNA Bands & Results & Interpretation \\
\hline HBV band & Positive & Positive for HBV \\
\hline HBV band & Negative & Proceed with nested amplification \\
\hline
\end{tabular}

\section{Results}

The study group of 100 blood donor specimens with HBsAg negative was males. The mean of ALT and TSB levels were $19.26 \pm 1.51 \mathrm{IU} / \mathrm{L}, 0.85 \pm 0.10 \mathrm{mg} / \mathrm{L}$ respectively and all specimens were underwent to further investigation with HBV serological markers as shown in table (4). Out of 100 samples $9(9 \%)$ had anti-HBc Total positive and $0 \%$ anti-HBc IgM negative. Out of 9 anti-HBc Total positive, $6(66.6 \%)$ was detected with anti-HBs positive, whereas $3(33.33 \%)$ was detected negative to anti-HBs. Furthermore, molecular detection of HBV DNA among the latter group with HBsAg negative and anti-HBc Total positive alone was done, one case $11.11 \%$ of this group was positive for HBV- DNA (Fig. 1).

Table (4): Seroprevalence of anti-HBc Total, anti-HBc IgM, anti-HBs and molecular estimation of HBV- DNA among HBsAg negative blood donors

\begin{tabular}{|c|c|c|c|c|c|}
\hline $\begin{array}{c}\text { No .of HBsAg } \\
\text { negative } \\
\text { specimen }\end{array}$ & $\begin{array}{l}\text { anti-HBc IgM } \\
\text { positive }\end{array}$ & $\begin{array}{c}\text { anti-HBc } \\
\text { Total } \\
\text { positive }\end{array}$ & $\begin{array}{c}\text { anti-HBc } \\
\text { Total } \\
\text { positive } \\
\text { and } \\
\text { anti-HBs } \\
\text { negative }\end{array}$ & $\begin{array}{c}\text { anti-HBc } \\
\text { Total positive } \\
\text { and } \\
\text { anti-HBs } \\
\text { positive }\end{array}$ & $\begin{array}{c}\text { HBV DNA } \\
\text { positive }\end{array}$ \\
\hline 100 & No. & No. & No. $\%$ & No. $\%$ & No. \\
\hline & $\mathbf{0}$ & 9 & \begin{tabular}{|ll}
3 & 33.33 \\
\end{tabular} & $\begin{array}{ll}6 & 66.66\end{array}$ & 11.11 \\
\hline
\end{tabular}

As well as the control group (patients specimens) which was routinely tested for HBV serological markers by ELISA table (5), also underwent for HBV-DNA detection by PCR assay (Fig. 2).



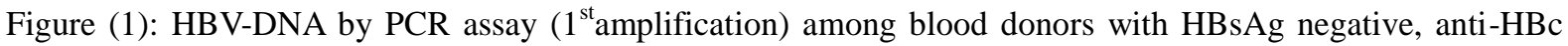
total positive and anti-HBs negative. Length of the fragments obtained from direct amplification of HBV-DNA: $270 \mathrm{bp}$ on $3 \%$ agarose gel at $100 \mathrm{v}$. for $45 \mathrm{~min}$. The results were read on UV transilluminator. (M: Molecular Weight Marker, 1: HBV DNA 270 bp 2 and 3: negative sample. PC positive control, NC: negative control).

\section{Discussion}

This result of serological markers table (4), shows out of $9 \%$ of blood donors who had $\mathrm{HBsAg}$ negative, anti-HBc Total positive and anti-HBc IgM negative, a $66.66 \%$ with a previous HBV infection and immunity to HBV regard to those who have together anti-HBc Total and anti-HBs positive together and this result is compatible with previously reported (Weinberger, et al., 2000; Jawetz, et al., 2007). While the latter group which accounted for $33.33 \%$ who were negative to anti-HBs and positive to anti-HBc Total, those possibilities include HBV infection in remote past; "low-level" HBV chronic carrier; "window" between disappearance of HBsAg and appearance of anti-HBs (CDC, 2008; WHO, 2013), although screening of HBsAg 
in blood donors massively decreased the risk of HBV transmission by transfusion, but did not identify pre-seroconversion window period infection (WPI) (Biswas, et al., 2003).

The results of PCR direct amplification showed (11.11\%) of latter group was positive for HBV- DNA which signified for presence of virus despite the absence of HBsAg and still capable of transmitting infection. This result is in agreement with that was reported by Lebanese researchers in 2007 , whom found that $5.4 \%$ of healthy blood donors with core antibody have detectable viral load (El-Zaatari, et al., 2007) as well as our results compatible with that was previously reported by Iranian researchers in 2013 whom found half of anti-HBc Abs positive samples were also positive for HBV-DNA among Iranian blood donors (Vaezjalali, et al., 2013). Also our results in line with recently published report in Malaysia, they were found that the 5.5\% prevalence of occult hepatitis B among Malaysian blood donors (Hudu, et al., 2016).The high percentage in this study may be due to the small size of the study population compared with above studies.

In regard to the patients groups (AHB, CHB and AHC), as shown in (Fig. 2) and table (5) the results of PCR amplification display insignificant differences $(\mathrm{P}>0.05)$ between routine serological tests that were accomplished by ELISA and PCR assay. This exhibited the precise and sensitivity of routine serological by ELISA assay that were used. In contrast to the blood donors group who had negative $\mathrm{HBsAg}$, positive anti-HBc Total and anti-HBs negative, the results of direct PCR amplification showed significant differences $(\mathrm{P}<0.05)$ in comparison with routine serological test by ELISA assay.

Table (5): Comparison between routine serological test by ELISA and PCR assay

\begin{tabular}{|l|c|c|c|}
\hline Type of infection & $\begin{array}{c}\text { No. of specimen } \\
\text { tested }\end{array}$ & $\begin{array}{c}\text { HBsAg positive } \\
\text { by routine ELISA } \\
\text { assay }\end{array}$ & $\begin{array}{c}\text { Positive } \\
\text { HBV--DNA by PCR }\end{array}$ \\
\hline AHB patients & 5 & 5 & $5^{*}$ \\
\hline CHB patients & 5 & 5 & $5^{*}$ \\
\hline HC group & 5 & 5 & $5^{*}$ \\
\hline $\begin{array}{l}\text { Blood donors } / \\
\text { HBsAg- negative }\end{array}$ & 100 & 0 & 16 \\
\hline \multicolumn{1}{|c|}{ Total } & 115 & 15 & $1^{* *}$ \\
\hline
\end{tabular}

* Insignificant difference between the two assays when $(P>0.05)$

${ }^{*}$ *Significant difference between the two assays when $(P<0.05)$

The results of blood donor who have HBV-DNA in the serum can be explanations through two possibilities; first suggestion, the antigen (HBsAg) is absent from the peripheral blood, and the absence could be due to mutations that block the export of the antigen, as described for certain pre-S deletion in HBV (Melegari, et al., 1994). Mutations in the S region have been associated with reduced expression of HBV surface proteins. Subsequently, mutations in pre S1/ pre S2 promoters are frequently observed in occult HBV patients, which make HBsAg become undetectable (Chaudhuri, et al., 2004; Vivekanandan, et al., 2008). In addition, the prevalence of HBV-DNA is high in anti-HBc- Total positive, but anti-HBs-negative patients, that ranging from $6 \%$ to $7 \%$ in population were highly exposed to HBV infection (Brechot, et al., 2001).

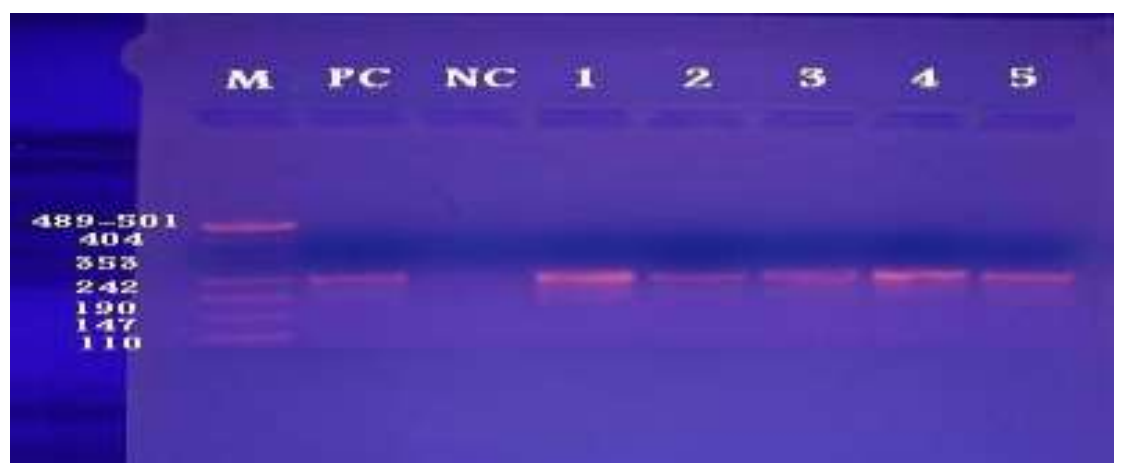

Figure (2): HBV-DNA in patient's serum by nested amplification. HBV-DNA bands obtained by nested PCR on $3 \%$ agarose gel at $100 \mathrm{v}$. for $45 \mathrm{~min}$. M: Molecular weight of marker. PC: positive control. NC: negative control. 1-5: DNA bands (258 bp) of $5 \mathrm{HBV}$ patients.

Second suggestion, The HBsAg is present but may not be detectable by standard enzyme immunoassay technique. It could be ascribed to the presence of circulating immune complex between HBsAg and anti-HBs which can worsen or even inhibit completely the detection of both the antigen and the antibody (Weinberger, et al., 2000; Brechot, et al., 2001). The first suggestion may be most likely explanation, because of routine methods seemed to be high sensitive when compared with PCR assay table (5). Occult hepatitis B is defined by the presence of HBV-DNA in serum or liver in the absence of HBsAg (Hu, 2002). And Occult hepatitis B 
infection is manifested by presence of very low levels $(<200 \mathrm{IU} / \mathrm{mL})$ of HBV -DNA in the blood and the liver while exhibiting undetectable HBV HBsAg (Martinez, et al., 2015) and detection of the anti-HBc Total in $80 \%$ of the cases. Moreover, in $20 \%$ of the cases there is no evidence of any HBV serological marker (Raimondo, et al., 2008). This type of infection represents a potential transmission source of HBV via blood transfusion or organ transplantation (Makvandi, 2016).

\section{Conclusions}

The anti-HBc Total is an important serological marker for detection of cases of occult $\mathrm{HBV}$ infection and for reducing the residual risk of HBV transmission via blood or blood product transfusion. And HBV-DNA is present in sera of blood donors with HBsAg negative, anti-HBc Total positive and anti-HBs negative. As well as high sensitive methods that was used for routine blood donors screening by ELISA in our laboratories. In this study we identify on case of occult HBV infection in blood donors by molecular and serological tests. Further screening studies of occult HBV infection in blood donors in different regions by using molecular detecting by PCR technique are necessary.

\section{References}

[1]. Biswas R, Tabor E, Hsia CC, Wright DJ, Laycock ME, Fiebig EW, et al., (2003), Comparative sensitivity of HBV NATs and HBsAg assays for detection of acute HBV infection. Transfusion; 43:788-98.

[2]. Brechot C., Thiers V., Kremsdorf D., Nalpas B., Pol S., Paterlini-Brechot P.,(2001). Persistent hepatitis B virus infection in subjects without hepatitis B surface antigen: clinically or purely "occult"? .Hepatology. 34:194-203.

[3]. Centers for Disease Control and Prevention (2008), Epidemiology and Prevention of Vaccine-Preventable Diseases. Atkinson W. Hamborsky J., Mclntyre I., Wolfe S., (eds). $10^{\text {th }}$ ed., Washington DC: Public Health Foundation. pp: 211-234.

[4]. http:// www.cdc.gov/vaccines/pubs/pinkbook/default.htm

[5]. Chaudhuri V, Tayal R, Nayak B, Acharya SK, Panda SK.m (2004), Occult hepatitis B virus infection in chronic liver disease: full-length genome and analysis of mutant surface promoter. Gastroenterology; 127: 1356-1371 [PMID: 15521005 DOI: 10.1053/j.gastro.2004.08.003]

[6]. El-Zaatari M, Kazma H, Naboulsi-Majzoub M, Haidar M, et al., (2007). Hepatitis B virus DNA in serum of "anti-HBc only"-positive healthy Lebanese blood donors: significance and possible implication. J. Hosp. Infect. 66: 278-82.

[7]. Ferguson M, Seagroatt V, Schild G., (1985), Proposed International Reference Preparation For Hepatitis B Surface antigen. In World Health Organization. Geneva: World Health Organization; 12-18.

[8]. Hass M, Hannoun C, Kalinina T, Sommer G, Manegold C, Günther S., (2005), Functional analysis of hepatitis B virus reactivating in hepatitis B surface antigen-negative individuals. Hepatology; 42: 93-103. PubMed. doi/10.1002/ hep.20748/full

[9]. Hu, K.Q., (2002), Occult hepatitis B virus infection and its implication. J. Viral. Hepat. 9:243-257.

[10]. Hudu, S. A., Harmal, N. S., Saeed, M. I., Alshrari, A. S., Malik, Y. A., Niazlin, M. T, et al., (2016), Molecular and serological detection of occult hepatitis B virus among healthy hepatitis B surface antigen-negative blood donors in Malaysia. Afri Health Sci; 16: 677-683. DOI: http://dx.doi.org/10.4314/ahs.v16i3.6.

[11]. Jawetz, Melnick, and Adelberg, (2007). In Medical Microbiology. Brooks, G. F., Butel, J. S., Morse, S. A., and Carroll, K. C., eds. $24^{\text {th }}$ ed. Mc Graw-Hill. pp: 466-485.

[12]. Li J., H., Guo, H., Gao, X. H., Chen H. D., (2015), Multiple skin ulcers from malignant syphilis. Lancet 386:1564. DOI: $10.1016 / \mathrm{S} 0140-6736(15) 60157-\mathrm{X}$.

[13]. Liang TJ. (2009), Hepatitis B: the virus and disease. Hepatology; 49: S13-S21.

[14]. Luo K.X., Liang Z.S., Yang S.C., Zhou R., Meng Q.H., Zhu Y.W., et al; (1993), Etiological investigation of acute post-transfusion non-A, non-B hepatitis in China. J. Med. Virol. 39: 219-223.

[15]. Makvandi M., (2016), Update on occult hepatitis B virus infection. World J Gastroenterol; 22: 8720-8734.htm DOI: http://dx.doi.org/10.3748/wjg.v22.i39.8720.

[16]. Martinez, M. C., Kok C. C., Baleriola C., Robertson, P., Rawlinson, W. D., (2015). Investigation of Occult Hepatitis B Virus Infection in Anti-HBc Positive Patients from a Liver Clinic. PLoS ONE 10: e0117275. DOI:10.1371/journal.pone.0117275

[17]. Melegari M., Bruno S., and Wands J. R., (1994), Properties of hepatitis B virus pre-S deletion mutants. Virology. 199: 292-300.

[18]. Raimondo G., Allain J. P., Brunetto M. R., Buendia M. A., Chen D. S., Colombo, M., et al., (2008), Statements from the Taormina expert meeting on occult hepatitis B virus infection. J Hepatol 49: 652-657. doi:10.1016/j.jhep.2008.07.014.

[19]. Rios-Ocampo, W. A., Cortes-Mancera, F., Olarte, J. C., Soto, A., and Navas, M-C., (2014) Occult Hepatitis B virus infection Among blood donors in Colombia. Virology Journal, 11:206. DOI: 10.1186/s12985-014-0206-z.

[20]. Song, J., E., and Kim, D.Y., (2016). Diagnosis of hepatitis B. Ann Transl Med; 4(18): 338. DOI: org/10.21037/atm.2016.09.11

[21]. Vaezjalali M, Rashidpour S, Rezaee H, Hajibeigi B, Zeidi M, Gachkar L, et al., (2013), Hepatitis B viral DNA among HBs antigen negative healthy blood donors. Hepat Mon; 13: e6590 [PMID: 23675384 DOI: 10.5812/ hepatmon.6590].

[22]. Vivekanandan, P., Kannangai, R., Ray, S. C., Thomas, D. L., Torbenson, M., (2008), Comprehensive genetic and epigenetic analysis of occult hepatitis B from liver tissue samples. Clin Infect Dis; 46: 1227-1236. DOI: 0.1086/529437.

[23]. Weinberger K. M., Bauer T., Böhm S. and Jilg W., (2000), High genetic variability of the group-specific $a$-determinant of hepatitis $\mathrm{B}$ virus surface antigen $(\mathrm{HBsAg})$ and the corresponding fragment of the viral polymerase in chronic virus carriers lacking detectable HBsAg in serum. Journal of General Virology. 81: 1165-1174.

[24]. World Health Organization (WHO). (2015). Hepatitis B. Fact sheet n²04. WHO, Available: http://www.who.int/mediacentre/factsheets/fs204/en/. Accessed 11 Jan 2016

[25]. World Health Organization. (2013), Hepatitis B Fact Sheet N204: Hepatitis B. World Health Organization. Available from: URL: http://www.who.int/mediacentre/factsheets/fs204/en/. Accessed January 23, 2013

[26]. Young D. S., (1997), Effects of drugs on clinical laboratory tests. $3^{\text {rd }}$ ed. AACC Press. (According to Linear chemical comp.). 